\title{
Suppression of Verticillium Wilt of Olive by Pseudomonas fluorescens
}

\author{
S. J. Sanei ${ }^{1 *}$ and S. E. Razavi ${ }^{1}$ \\ ${ }^{1}$ Department of Plant Protection, Gorgan University of Agricultural Sciences \\ and Natural Resources, Gorgan, Iran.
}

Research Article

Received $10^{\text {th }}$ July 2011

Accepted $14^{\text {th }}$ August 2011

Online Ready $8^{\text {th }}$ September 2011

\begin{abstract}
Protection of pathogen-free olive planting material from infection by Verticillium dahliae during plant propagation and/or at planting would help in the management of Verticillium wilt of olive. Despite the importance for rhizosphere functioning, rhizobacterial Pseudomonas spp. have been mainly studied in a cultivation-based manner. In this study, 8 isolates of Pseudomonas fluorescens obtained from roots of olive plants were tested for suppression of Verticillium wilt in nursery-produced olive planting stocks under controlled conditions. The antagonistic activity of $P$. fluorescens isolates from olive against defoliating (D) and nondefoliating (ND) $V$. dahliae pathotypes. The isolates of $P$. fluorescens isolates from olive varied in the ability to inhibit hyphal growth of $D$ and ND $V$. dahliae on PDA. In planta bioassays were conducted under greenhouse conditions, by inoculating bacterial-treated and -nontreated 3- to 4-month-old, own-rooted plants of susceptible olive cv. Zard with the highly and less virulent $V$. dahliae. Results indicated that root treatment with some of $P$. fluorescens isolates significantly reduced the final disease incidence and severity, compared with the nontreated controls. Our results indicate that root treatment of olive plants with selected $P$. fluorescens isolates during nursery propagation can help in the biocontrol of $V$. dahliae in olive especially for ND pathotypes. No correlation was found between efficacy of tested bacterial isolates for in vitro antagonism of the pathogen and in planta suppression of Verticillium wilt.
\end{abstract}

Keywords: Olea europaea; Pseudomonas fluorescens; Verticillium dahliae; biological control; 


\section{INTRODUCTION}

Wilting disease of olive caused by Verticillium dahliae Kleb. is widespread wherever this crop is grown (Levin et al., 2003; Sanei et al., 2010). In Iran, Verticillium wilt of olive was first reported in Golestan province, the northern of Iran in 1996 (Sanei et al., 1996), and subsequently in many other region (Sanei et al., 2010). The disease is most damaging on young plants, while on older plants, including those over 20-year-old, the disease does not normally kill the plant, but reduces vegetation and causes partial defoliation of one or more branches (Sanei et al., 2004). There has been a remarkable increase in the olive tree inventory in recent years in Iran especially in Golestan province. In this province nearly 10,000 hectar of olive orchards are present, which represents about $20 \%$ of total national olive area (Anonymous, 2009). Commercial cultivars of olive are planted in Iran but wild olives are the important genetical sources of olive, that residue of them can be seen in the East of Golestan province (Sanei et al., 2005).

Severity of Verticillium wilt in olive is strongly influenced by virulence (i.e., the amount of disease caused in a host genotype) of the pathogen isolates. $V$. dahliae infecting olive can be classified as defoliating (D) or nondefoliating (ND) pathotypes according to their ability to defoliate or not the plant, respectively (Sanei and Nasrollahnejad, 1995; Sanei et al., 2004; 2008). Olive plants infected with the ND pathotype can recover from symptoms while olive plants infected with the D pathotype can die (Mercado-Blanco et al., 2003; Lopez-Escudero and Blanco-Lopez, 2005). Verticillium dahliae produce melanized resting structures, microsclerotia. These structures that develop in senescing tissues of the dead plant can freely survive in soils for several years without losing viability. The pathogen can survive for 14 years or more in soil as microsclerotia, which are small, multicellular and melanized structures (Soesanto and Termorshuizen, 2001). Microsclerotia are stimulated to germinate by root exudates. The infectious hyphae that emerge from the microsclerotia penetrate the roots of the host plant. Because the microsclerotia are the most important structures of the pathogen for survival and in causing initial infections, the microsclerotia are regarded as one of the direct targets of biological control of Verticillium (Sanei et al., 2000; Tjamos, 2000).

Verticilium wilt is among the most difficult diseases to control, and the efficacy of current strategies for management of this disease is limited (Sanei et al., 2010). Pre-planting soil fumigation is widely used throughout the world to control wilt for high-value crops. However, most of the synthetic fumigants create several side effects in the forms of carcinogenicity, teratogenicity and residual toxicity. Human health, environment concern and consumers' demand for residue-free food necessitate the evaluation of alternative, reduced-risk control methods. Therefore, some alternative biological control measures should be discovered to replace synthetic pesticides for pest management without creating any pesticidal pollution. In the past, studies on biological control of Verticillium microsclerotia have typically focused on the use of the fungus Talaromyces flavus. This fungal antagonist kills individual Verticillium microsclerotia in vitro, because of the production of glucose oxidase that converts glucose to hydrogen peroxide (Fravel et al., 1987; Kim et al., 1988; Fahima et al., 1992; Nagatzaam, 1995; Naraghi and Heydari, 2006). In recent years, bacterial antagonists, e.g. Pseudomonas spp., have also been identified as potential biological control agents for Verticillium wilt (Azad- Disfani et al., 2000; Drofenigg et al., 2009; Debode et al., 2007; Mercado-Blanco et al., 2004; Prieto et al., 2009). These previous studies have specifically targeted the suppression of the hyphal growth of Verticillium. However, to our knowledge, limited research has ever looked at the direct effect of these bacterial antagonists on the viability of individual Verticillium microsclerotia in vitro. As mentioned, a better control of microsclerotia 
is important, as they are the key structures responsible for survival and infection by Verticillium.

The objective of this research was to determine whether root-associated Pseudomonas isolated from olive can be effective in protecting nursery-produced olive planting stocks from infection by the highly virulent $D$ and less virulent ND $V$. dahliae.

\section{MATERIALS AND METHODS}

\subsection{Bacterial Strains and Culture Conditions}

Eight isolates of Pseudomonas fluorescens, namely isolates P1-P8 were used in this research. These bacteria were isolated from roots of nursery-propagated olive plants cv. Zard kindly provided by Tehran University, Plant protection department. For bacterial isolations, olive roots were washed under running tap water, surface disinfested in $\mathrm{NaClO}$ $(0.5 \%$ available chlorine) for $3 \mathrm{~min}$, rinsed thoroughly in sterile water, and ground with an autoclaved pestle and mortar in $10 \mathrm{mM} \mathrm{MgSO} 4.7 \mathrm{H} 2 \mathrm{O}$. Aliquots of macerates were plated on King's medium B agar (KBA) (Mercado-Blanco et al., 2004) and incubated at $25^{\circ} \mathrm{C}$ for $48 \mathrm{~h}$. Single bacterial colonies were transferred to KBA slant and cultures were stored in $4^{\circ} \mathrm{C}$. The Olive isolates of $V$. dahliae (defoliating and nondefoliating pathotypes) was used from previous study (Sanei et al., 2008). The cultures were also stored in $4^{\circ} \mathrm{C}$.

\subsection{In Vitro Inhibition of V. dahliae Hyphal Growth by Bacteria}

$P$. fluorescens isolates from olive were tested for their ability to inhibit the hyphal growth of $V$. dahliae isolates (defoliating and nondefoliating pathotypes) in vitro. Assays were performed in petri plates containing $15 \mathrm{ml}$ of PDA. Bacterial suspensions in $10 \mathrm{mM}$ MgSO 4.7H2O were adjusted to a final concentration of $10^{8} \mathrm{cells} / \mathrm{ml}$. Two $5 \mu \mathrm{l}$ droplets of a bacterial suspension were spotted per plate, $1 \mathrm{~cm}$ from the opposite edges of a plate and opposite each other. Bacteria were incubated at $28^{\circ} \mathrm{C}$ for $48 \mathrm{~h}$ and a suspension of $5 \times 10^{4}$ conidia/ml of either $V$. dahliae VD or VND was sprayed over the plates. The bacterial and fungal isolates were plated separately as controls. Cultures were incubated at $25^{\circ} \mathrm{C}$ for $72 \mathrm{~h}$, and the antagonistic activity by bacteria was assessed by the presence of a zone without fungal growth surrounding the bacterial colony. Each combination of microorganisms, controls, and culture media were replicated three times in a randomized complete block design and the experiment was repeated once.

\subsection{Root Colonization Assay}

An experiment was conducted to determine the ability of $P$. fluorescens isolates from olive to colonize olive roots. Six-month-old olive plants cv. Zard (Susceptible to Verticillium wilt, Sanei et al., 2004) were carefully uprooted from the substrate, their roots thoroughly washed in tap water without intentional wounding, and dipped in a bacterial suspension $\left(5 \times 10^{4}\right.$ cells $/ \mathrm{ml}$ ) for $10 \mathrm{~min}$. For the control treatment, plants were treated similarly except that roots were dipped in $10 \mathrm{mM} \mathrm{MgSO}{ }_{4} \cdot 7 \mathrm{H}_{2} \mathrm{O}$. Plants were then transplanted (one per pot) into $15-$ cmdiameter clay pots filled with an autoclaved $\left(121^{\circ} \mathrm{C}, 1 \mathrm{~h}\right.$, twice on consecutive days) soil mixture (sand/loam, 2:1, vol/vol). There were four replicated plants for each bacterial treatment in a randomized complete block design. Plants were incubated under greenhouse conditions. The air temperature during the experiment fluctuated between $18^{\circ} \mathrm{C}$ and $33^{\circ} \mathrm{C}$. Plants were watered as needed. To determine colonization of root tissue by bacteria, plants 
were uprooted delicately from pots and the root systems were thoroughly washed under running tap water, dried with sterile filter paper, and cut into $1-\mathrm{cm}$ long pieces. For each plant, samples of $2 \mathrm{~g}$ of root pieces were surface-deinfested in $1 \% \mathrm{NaOCl}$ for $3 \mathrm{~min}$, washed three times in sterile distilled water, and ground in $10 \mathrm{ml}$ of $10 \mathrm{mM} \mathrm{MgSO} \mathrm{M}_{4} .7 \mathrm{H}_{2} \mathrm{O}$ using an autoclaved pestle and mortar (Mercado-Blanco et al., 2001a, 2002). Serial dilutions of the macerates were plated onto modified $\mathrm{KB}$ and incubated at $25^{\circ} \mathrm{C}$ for $48 \mathrm{~h}$. Then, bacterial colonies were counted and bacterial populations were expressed as colony-forming units (cfu)/g of fresh root tissue.

\subsection{Suppression of Verticillium Wilt of Olive by Bacteria}

To determine the ability of $P$. fluorescens isolates to suppress Verticillium wilt of olive caused by the $V$. dahliae pathotypes, Nursery-propagated, own-rooted olive plants cv. Zard were used. Olives were shown to be more susceptible to V. dahliae in previous studies (Sanei et al., 2004). 6-month-old olive plants were propagated by rooting of leafy stem cuttings under mist conditions in plastic tunnels. Plants were root-dip inoculated with a bacterial suspension $\left(5 \times 10^{8}\right.$ cells $\left./ \mathrm{ml}\right)$ or root dipped in $10 \mathrm{mM} \mathrm{MgSO}{ }_{4} .7 \mathrm{H}_{2} \mathrm{O}$ (controls) as described above for the root colonization assay. Then, inoculated and control plants were transplanted into $15-\mathrm{cm}$ diameter clay pots (one plant per pot) filled with the autoclaved soil mixture infested with conidia of the pathogen. The soil mixture was infested by thoroughly mixing $100 \mathrm{ml}$ of a conidial suspension $(2 \times 107$ conidia/ml) of $V$. dahliae isolate with $1 \mathrm{~kg}$ of the mixture to obtain a final concentration of $2 \times 10^{6}$ conidia/g of soil. There were four replicated blocks in a randomized complete block design, each block comprising three pots. Plants were incubated in a greenhouse. The air temperature during the experiment fluctuated between $18^{\circ} \mathrm{C}$ and $33^{\circ} \mathrm{C}$.

The symptoms were rated 7 months after inoculation on a 0 to 4 scale according to Tjamos et al. (1991). To evaluate wilt resistance, disease severity was assessed weekly for 10 weeks, starting 2 weeks after inoculation. A scale $0-4$ was used according to the percentage of plant tissue affected by chlorosis, leaf and shoot necrosis or defoliation ( $0=$ absence of symptoms, $1=$ light foliar symptoms in $1-9 \%$ of plant canopy, $2=$ moderate foliar symptoms and light defoliation (10-25\%), 3=severe foliar symptoms and moderate defoliation (26$50 \%$ ) and $4=$ total defoliation or plant death). The percentage of dead plants (PDP), recovery from the disease (L'opez-Escudero and Blanco-Lopez, 2001; Hiemstra, 1998; Wilhelm and Taylor, 1965) and other symptoms such as marginal spots of leaves and irregular growth of twigs were also considered to estimate the severity of reactions. The area under the disease progress curve (AUDPC) was estimated for each cultivar considering its percentage with regard to the maximum possible value that could be reached in the 10 weeks period of assessment based on Campbell and Madden (1990): AUDPC $=\left[\left(t / 2 *\left(S 2+2 * S 3_{+} \cdot \cdots+\right.\right.\right.$ $2 S i-1+S i) / 4 * n] * 100(t=$ interval in days between observations; $S i=$ final mean severity; 4 $=$ maximum disease rating; $n=$ number of observations). Plant infection was verified by the isolation of the fungus from affected shoots or leaf petioles of affected plants during the experiments. Plants were arranged according to a split-plot completely randomised block design. The mainplot was the $V$. dahliae pathotype, and cultivars were assigned to sub-plots. The analysis of variance (ANOVA) of AUDPC of reference-cultivars in each experiment was performed to determine the variability among experiments. In experiments where reactions of cultivars were statistically different, values of AUDPC of cultivars included in these experiments were corrected regarding the percentage of the difference between the values of AUDPC for reference-cultivars in significant and non-significant experiments. Statistical analysis was performed by SPSS 11.0 program. Mean values were compared by the Duncan's protected LSD at $P=0.05$. 
To determine the colonization index, all leaves of inoculated and non-inoculated (control) cuttings were removed and the stem was disinfected by $1 \% \mathrm{NaOCl}$ for 10 min, washed, dried and its epidermis peeled. Four segments $(5 \mathrm{~mm}$ length) from each of two different parts (see below) were cut and placed on PDA medium for 14 days at $25^{\circ} \mathrm{C}$. Once $V$. dahliae was detected the segment was considered as infected. Colonization index (I) was calculated as follows: I $1 / 4\left(2^{*} \mathrm{Nb}+6^{*} \mathrm{Nt}\right) / \mathrm{N}$, where $\mathrm{Nb}$, is the number of infected segments at the base of the stem- cutting ( $1 \mathrm{~cm}$ above tube rim), and $\mathrm{Nt}$ is the number of infected segments at the top $(8 \mathrm{~cm}$ above tube rim), and $\mathrm{N}$ is the total number of tested segments. The number of infected segments from the base and upper parts was multiplied by the coefficient factors of 2 , and 6 , respectively, resulting in a calculated colonization index in range between 0 and 8 . As detection of $V$. dahliae in the upper parts of the stem is more rare than in the base, detection in the upper parts may reflect a higher level of plant colonization (Tsror (Lahkim) et al., 1998, 2001).

\section{RESULTS AND DISCUSSION}

\subsection{In Vitro Inhibition of V. dahliae Hyphal Growth by Bacteria}

The isolates of $P$. fluorescens isolates from olive varied in the ability to inhibit hyphal growth of $D$ and ND $V$. dahliae on PDA (Table 1). While P2 and P7 isolates were highly inhibitory to both $V$. dahliae pathotypes, some isolates (P3 and P9) did not. The ability of bacterial strains to inhibit growth of $V$. dahliae on PDA was not influenced by the nature of pathotype (Table 1).

Table 1. Hyphal growth inhibition of defoliating and nondefoliating $V$. dahliae isolates on PDA and KBA media by $P$. fluorescens isolated from olive ${ }^{a}$

\begin{tabular}{lll}
\hline \multirow{2}{*}{ Bacteria } & \multicolumn{2}{c}{ Growth inhibition of $\boldsymbol{V}$. dahliae on } \\
\cline { 2 - 3 } & \multicolumn{2}{c}{ PDA } \\
& VD & VND \\
\hline Pf1 & $20.4 \mathrm{a}^{\mathrm{b}}$ & $21.2 \mathrm{a}$ \\
Pf2 & $25.3 \mathrm{a}$ & $24.4 \mathrm{a}$ \\
Pf3 & $2.5 \mathrm{c}$ & $2.6 \mathrm{c}$ \\
Pf4 & $12 \mathrm{~b}$ & $13.2 \mathrm{~b}$ \\
Pf5 & $23 \mathrm{a}$ & $23 \mathrm{a}$ \\
Pf6 & $2.3 \mathrm{c}$ & $2.5 \mathrm{c}$ \\
Pf7 & $10.8 \mathrm{~b}$ & $11.2 \mathrm{~b}$ \\
Pf8 & $12.1 \mathrm{~b}$ & $11.7 \mathrm{~b}$ \\
\hline
\end{tabular}

a Suspensions of $P$. fluorescens isolates were spotted (5 $\mu$ droplets) onto media, incubated at $28^{\circ} \mathrm{C}$ for $48 \mathrm{~h}$, and then sprayed with conidia of $V$. dahliae isolates. Plates without bacteria were used as control. There were four replicated plates for each bacterium-fungal isolate-culture medium combination and the experiment was repeated once, zone of hyphal growth inhibition (halo) around the bacterial colony.

$b$ For each experiment, means in a column followed by an asterisk are significantly different from the mean of the control treatment according to Duncan's test $(P=0: 05)$.

\subsection{Root Colonization Assay}

The population sizes of total fluorescent pseudomonas determined on modified KBA were significantly higher compared with that in roots of control plants. Mean population sizes of some $P$. fluorescens isolates were significantly higher than others (Table 2). 
Table 2. Population sizes of isolates of $P$. fluorescens recovered from root tissues of olive cv. Zard after root-dip inoculation with bacterial suspensions ${ }^{a}$

\begin{tabular}{lc}
\hline Bacteria & $\begin{array}{c}\text { Bacterial population } \\
\text { (log CFU/g of fresh root) on KBA }\end{array}$ \\
\hline Pf1 & $5.7 \mathrm{a}^{\mathrm{b}}$ \\
Pf2 & $3.9 \mathrm{c}$ \\
Pf3 & $4.2 \mathrm{~b}$ \\
Pf4 & $4.5 \mathrm{~b}$ \\
Pf5 & $4.6 \mathrm{~b}$ \\
Pf6 & $5.8 \mathrm{a}$ \\
Pf7 & $5.3 \mathrm{a}$ \\
Pf8 & $4.1 \mathrm{~b}$ \\
Control (no bacteria) & $2.7 \mathrm{~d}$ \\
\hline
\end{tabular}

a The root system of 6-month-old olive plants were dipped in $5 \times 10^{8} \mathrm{cells} / \mathrm{ml}$ in $10 \mathrm{mM} \mathrm{MgSO}$.7H2O bacterial suspension for $10 \mathrm{~min}$. Control plants were dipped in a sterile solution of $10 \mathrm{mM}$ MgSO4_7H2O. Plants were transplanted into autoclaved soil and grown in a greenhouse for 3 months. Populations of bacteria were determined on King's medium B agar (KBA). Data are means of four 2-g fresh root samples (one sample per plant).

$b$ For each experiment, means in a column followed by an asterisk are significantly different from the mean of the control treatment according to Duncan's test $(P=0: 05)$.

\subsection{Suppression of Verticillium Wilt of Olive by Bacteria}

Symptoms developed neither in noninoculated controls nor in plants treated with the bacterial isolates grown in noninfested soil in experiment. Treatment of roots of 6-month-old, rooted olive stem cuttings with $P$. fluorescens isolates influenced the development of Verticillium wilt in cv. Zard (Table 3). Nontreated, inoculated plants grown in V. dahliae pathotypes-infested soil showed symptoms characteristic of those caused by the pathotypes in olive cv. Zard. In those plants, first symptoms developed by 33 days after inoculation with defoliating pathotypes, but bacterization with $P$. fluorescens significantly delayed the by 14 days and reduced significantly the final disease severity compared with the control. There was significantly difference between suppression of Verticillium wilt of olive by bacteria. To confirm infection by the pathogen, isolations of the fungus were carried out from the stems and roots of symptomless and diseased plants. Results indicated that positive isolation of the fungus did correlate with severity of symptoms in the plant (data not shown).

Management of Verticillium wilts of woody hosts such as olive is difficult and should be based on an integrated strategy (Tjamos, 1993). Exploiting the potential of microbial antagonists for the protection of olive planting material would be a desirable pre-planting measure for the integrated management of Verticillium wilt. The main objective of the present work was to determine the ability of olive root-associated Pseudomonas spp. to protect planting material of the highly susceptible olive cv. Zard against Verticillium wilt caused by the highly virulent $D$ and less virulent ND pathotype of $V$. dahliae. The bacteria adapted to occupy the plant infection court might be good candidates to prevent or reduce efficiency of the pathogen to invade the plant and cause disease. the use of root-associated bacteria for control of Verticillium wilt in a woody host such as olive. The Pseudomonas spp. isolates used in this work were isolated from internal root tissues of nursery-produced olive plants, and their ability to thoroughly colonize the olive root system was confirmed by root colonization assays of Zard olive planting stocks from different sources using the Pseudomonas wild-type isolates. Indigenous Pseudomonas spp. were isolated from root 
tissues of the olive plants inoculated with the selected bacteria. However, the population sizes of total pseudomonads recovered from treated roots was significantly higher than those of nontreated, control plants, thus making possible to distinguish the introduced Pseudomonas isolates.

Table 3. Effect of treatment of rooted olive stem cuttings with isolates of $P$. fluorescens isolates from olive on development of Verticillium wilt and growth of olive cv. Zard in soil infested with defoliating and nondefoliating V. dahliae ${ }^{a}$

\begin{tabular}{lcccccc}
\hline \multirow{2}{*}{ Treatment } & \multicolumn{3}{c}{ Defoliating } & \multicolumn{3}{c}{ Non-defoliating } \\
\cline { 2 - 7 } & AUDPC & PDP & Cl $^{\mathbf{c}}$ & AUDPC & PDP & Cl \\
\hline Control & $85.4 \mathrm{a}^{\mathrm{b}}$ & 100 & $2.5 \mathrm{a}$ & $68.9 \mathrm{a}$ & 20 & $2 \mathrm{a}$ \\
Pf1 & $25.2 \mathrm{~d}$ & 30 & $1.5 \mathrm{~b}$ & $11.1 \mathrm{~d}$ & 0 & $1 \mathrm{~b}$ \\
Pf2 & $22.8 \mathrm{~d}$ & 20 & $1.5 \mathrm{~b}$ & $12.8 \mathrm{~d}$ & 0 & $1 \mathrm{~b}$ \\
Pf3 & $81.4 \mathrm{a}$ & 90 & $2.5 \mathrm{a}$ & $57.2 \mathrm{a}$ & 30 & $2 \mathrm{a}$ \\
Pf4 & $66.2 \mathrm{~b}$ & 60 & $2 \mathrm{ab}$ & $36.7 \mathrm{~b}$ & 10 & $1.5 \mathrm{ab}$ \\
Pf5 & $68.6 \mathrm{~b}$ & 50 & $2 \mathrm{ab}$ & $34.3 \mathrm{~b}$ & 0 & $1.5 \mathrm{ab}$ \\
Pf6 & $77.8 \mathrm{~b}$ & 100 & $2 \mathrm{ab}$ & $54.9 \mathrm{a}$ & 30 & $2 \mathrm{a}$ \\
Pf7 & $57 \mathrm{c}$ & 70 & $2 \mathrm{ab}$ & $23.7 \mathrm{c}$ & 0 & $1 \mathrm{a}$ \\
Pf8 & $80.3 \mathrm{a}$ & 100 & $2.5 \mathrm{a}$ & $53.1 \mathrm{a}$ & 10 & $2 \mathrm{a}$ \\
\hline
\end{tabular}

aThe root systems of 4-month-old, own-rooted plants were dipped in $5 \times 10^{8}$ cells/ $\mathrm{ml}$ bacterial suspensions in $10 \mathrm{mM} \mathrm{MgSO} 4.7 \mathrm{H} 2 \mathrm{O}$ or a sterile $10 \mathrm{mM} \mathrm{MgSO} 4.7 \mathrm{H} 2 \mathrm{O}$ solution (control) for $10 \mathrm{~min}$, then transplanted into autoclaved soil artificially infested with $2 \times 10^{6}$ conidia/g of defoliating $\mathrm{V}$. dahliae pathotypes and grown in the greenhouse for 70 days. A disease severity of symptoms recorded at 7day-intervals.

$b$ For each experiment, means in a column followed by an asterisk are significantly different from the mean of the control treatment according to Duncan's test $(P=0: 05)$.

c Nine-month-old olive plants were inoculated with defoliating or non-defoliating isolates of $V$. dahliae. Symptom severity was assessed weekly from 2 to 12 weeks after inoculation. AUDPC= area under the disease progress curve; $P D P=$ percentage of dead plants; $\mathrm{Cl}=$ colonization index

A common mechanism underlying the direct antagonistic activity towards soil pathogens by Pseudomonas is the production of antifungal compounds. These antifungal compounds include the secretion of antibiotics and siderophores (Dwivedi and Johri, 2003), biosurfactants (Raaijmakers et al., 2006) and lytic enzymes (Velazhahan et al., 1999). Isolates of $P$. fluorescens varied in their ability to suppress Verticillium wilt of olive under conditions favorable for severe disease. Also, the degree of Verticillium wilt suppression by $P$. fluorescens isolates varied among the $V$. dahliae pathotypes. Lack of consistency in the performance of Pseudomonas spp. and Bacillus spp. as biocontrol agents under field conditions has often been one of the factors limiting the use of them in commercial agriculture (Berg et al., 1994; Hall et al., 1986; Leben et al., 1987; Raaijmakers et al., 2002). Much of that inconsistency has been attributed to variability in the physical and chemical properties within the niches occupied by biocontrol agents, as well as the plant, that affect both colonization and expression of biocontrol mechanisms (Niu et al., 1999). Nevertheless, it was interesting to note that significant disease suppression was achieved when severe Verticillium wilt developed in nontreated, control plants regardless environmental conditions. In contrast, Verticillium wilt development was not significantly influenced by the same Pseudomonas spp. isolates tested on the same olive plant material and culture conditions. It is possible to speculate that potential for biocontrol activity by those bacteria was not revealed because of low disease pressure in some conditions. Therefore, the enhanced growth of $V$. dahliae-inoculated olive plants by some of the tested bacteria could just be 
attributable to counteracting of deleterious effects caused by the pathogen in infected plants, rather than actual stimulation of the plant growth (Mercado-Blanco and Bakker, 2007; Mercado-Blanco et al., 2004, 2009). Moreover, no significant differences in plant growth promotion were found among olive plants treated with the different bacteria tested, as well as between treated and untreated plants in the absence of the pathogen (Mercado-Blanco et al., 2004). Several mechanisms have been proposed for disease suppression mediated by nonpathogenic Pseudomonas: production of antibiotics, siderophores, HCN, and lytic enzymes, competition for nutrients and suitable niches on a root surface, and induction of systemic resistance (Baidez et al., 2007; van Loon et al., 1998). The mechanism(s) that could be involved in the suppression of Verticillium wilt of olive by some of the bacteria are not known yet and their precise role can only be analyzed using deficient mutants. However, as a first step to assess capabilities by these bacteria, are able to production of pseudobactin (and probably other siderophores) and HCN, which showed inhibitory activity against $V$. dahliae in vitro (Mercado-Blanco and Bakker, 2007; Mercado-Blanco et al., 2004). The results indicate that there was no correlation between in vitro antagonism against $V$. dahliae (Table 1) and in vivo suppression of Verticillium wilt of olive by the tested bacteria (Table 2). This lack of correlation between antagonism under in vitro conditions and efficacy in disease suppression is not uncommon in plant disease biocontrol, and has been reported elsewhere (van Loon et al., 1998; Wang et al., 2004).

Contrary to the common assumption that melanized structures are resistant to microbial attack (Bell and Wheeler, 1986). Mercado-Blanco et al., (2004) showed that Pseudomonas spp. can suppress the viability of Verticillium microsclerotia in vitro. Reduction in Verticillium microsclerotia germination and formation of secondary microsclerotia may result in a lower Verticillium infection pressure in the field and in a reduced survival of Verticillium microsclerotia in soil. Thus, this study suggests that Pseudomonas spp. may be promising biological agents to control Verticillium wilt and they deserve closer attention in future field studies. hypothesized that secondary metabolites might be involved in their mode of action, as secondary metabolites are mainly produced by bacteria at high cell densities (Haas et al., 2000).

Microsclerotia colonization and competition for nutrients apart from secondary metabolites, a second possible underlying mechanism that may be involved in the Pseudomonas-mediated reduction of Verticillium microsclerotia viability is the ability of Pseudomonas spp. to colonize microsclerotia and utilize nutrients from the microsclerotia for their own growth. If this is the case, microsclerotia germination will be most likely inhibited, as these nutrients are normally used by the microsclerotia themselves for their germination (Willetts and Bullock, 1992). However, it can also be hypothesized that Pseudomonas spp. might utilize the nutrients that are released by the microsclerotia. The release of nutrients by sclerotia in so-called 'exudation droplets' has been suggested to play an important role in maintaining the physiological balance within sclerotia (Willetts and Bullock, 1992). Therefore, it can be hypothesized that when Pseudomonas spp. utilize the nutrients released in the exudation droplets, it follows that the physiological balance of the microsclerotia gets disturbed and the germination of the microsclerotia is inhibited. The present study shows that Pseudomonas spp. might colonize the surface of the microsclerotia, but not the inner matrix. The adhesion of bacteria on the surface of the pathogen is an important feature in antagonistic interactions (Jana et al., 2000) and our results support that this mechanism may play a role in the biocontrol activity of the tested Pseudomonas strains.

As until now no single mode of action could be demonstrated, we believe that there might be interference between the modes of actions. For example, biosurfactants and phenazines 
might act synergistically in the biological control of plant pathogens (Perneel, 2006). Preliminary results showed that the combined incorporation of the tested Pseudomonas spp. with ryegrass or lignin in soil was more effective in reducing the viability of the Verticillium microsclerotia than the application of the Pseudomonas spp. alone (Debode et al., 2007). These results indicate that in field conditions, a combined treatment may be more successful in controlling Verticillium than the application of Pseudomonas spp. alone.

\section{CONCLUSION}

This present study demonstrate the potential of some native, root-associated bacteria from olive as effective biocontrol agents against $V$. dahliae pathotypes, especially nondefoliate isolates in nursery-produced olive planting stocks. The efficacy of some of those bacteria (when introduced either alone or in combination) for biocontrol of Verticillium wilt in adult olive plants, as well as studies on the mechanism(s) involved in disease suppression are scopes of future research.

\section{REFERENCES}

Anonymous. (2009). Agriculture Information for 2007, vol. 1, Jahad and Agricultural Ministry, $152 \mathrm{p}$.

Azad- Disfani, F., Shari-Tehrani, A., Hedjaroode, A., Mohammadi, M., Rohani, H. (2000). Study on antagonistic properties of Bacillus and Pseudomonas isolates against Verticillium dahliae, the causal of cotton wilt. $14^{\text {th }}$ Iranian Protection Congress, 5-8 Sep., p. 57.

Baidez, A.G., Gomez, P., Del Rio, J.A., Ortuno, A. (2007). Dysfunctionality of the xylem in Olea europaea L. plants associated with the infection process by Verticillium dahliae Kleb. Role of phenolic compounds in plant defense mechanism. Journal Agricultural Food Chememistry, 55, 3373-3377.

Bell, A.A., Wheeler, M.H. (1986). Biosynthesis and function of fungal melanins. Annual Review of Phytopathology, 24, 411-451.

Berg, G., Knaape, C., Ballin, G., Seidel, D. (1994). Biological control of Verticillium dahliae Kleb. by natural occurring rhizosphere bacteria. Arch Phytopath Pflanz, 29, 249-262.

Debode, J., De Maeyer, K., Perneel, M., Pannecoucque, J., De Backer, G., Hofte, M. (2007). Biosurfactants are involved in the biological control of Verticillium microsclerotia by Pseudomonas spp. Journal of Applied Microbiology, 103, 1184-1196.

Drofenigg, K., Aranda, S., Landa, B.B., Berg, G., Muller, H. (2009). Cultivar specific Pseudomonas communities in the rhizosphere of olive trees. Proceedings of the $10^{\text {th }}$ International Verticillium Symposium. Corfu Island, Hellas, p. 108.

Dwivedi, D., and Johri, B.N. (2003). Antifungals from fluorescent pseudomonads: biosynthesis and regulation. Current Science India, 85, 1693-1703.

Fahima, T., Madi, J. and Henis, Y. (1992). Ultrastructure and germinability of Verticillium dahliae microsclerotia parasitized by Talaromyces flavus on agar medium and in treated soil. Biocontrol Sciences and Technology, 2, 69-78.

Fravel, D.R., Kim, K.K., Papavizas, G.C. (1987). Viability of microsclerotia of Verticillium dahliae reduced by a metabolite produced by Talaromyces flavus. Phytopathology 77, 616-619.

Hall, H.T.J., Schreiber, L.R., Leben, C., (1986). Effects of xylem colonizing Bacillus spp. on Verticillium wilt in maples. Plant Disease, 70, 521-524. 
Haas, D., Keel, C. (2003). Regulation of antibiotic production in root-colonizing Pseudomonas spp. \& relevance for biological control of plant disease. Annual Review of Phytopathology, 41, 117-153.

Hiemstra, J.A. (1998). Some general features of Verticillium wilts in trees. In: Hiemstra, J.A., Harris, D.C. (Eds.), A Compendium of Verticillium Wilts in Tree Species. Ponsen and Looijen, the Netherlands: Wageningen, pp. 5-12.

Jana, T.K., Srivastva, A.K., Csery, K., Arora, D.K. (2000). Agglutination potential of Pseudomonas fluorescens in relation to energy stress and colonization of Macrophomina phaseolina. Soil Biology and Biochemistry, 32, 511-519.

Kim, K.K., Fravel, D.R., Papavizas, G.C. (1988). Identification of a metabolite produced by Talaromyces flavus as glucose-oxidase and its role in the biocontrol of Verticillium dahliae. Phytopathology, 78, 488-492.

Leben, S.D., Wadi, J.A., Easton, G.D. (1987). Effects of Pseudomonas fluorescenson potato plant growth and control of Verticillium dahliae. Phytopathology 77, 1592-1595.

Levin, A.G., Lavee, S., Tsror (Lahkim), L. (2003). Epidemiology of Verticillium dahliae on olive (cv. Picual) and its effect on yield under saline conditions. Plant Pathology, 52, 212-218.

Lopez-Escudero, F.J., Blanco-Lopez, M.A. (2005). Recovery of young olive trees from Verticillium dahliae. European Journal of Plant Pathology, 113, 367-375.

Mercado-Blanco, J., Bakker, P.A.H.M. (2007). Interactions between plants and beneficial Pseudomonas spp.: exploiting bacterial traits for crop protection. Antonie van Leeuwenhoek, 92, 367-389.

Mercado-Blanco, J., Rodrıguez-Jurado, D., Parrilla-Araujo, S., Jimenez- Dıaz, R.M. (2003). Simultaneous detection of the defoliating and nondefoliating Verticillium dahliae pathotypes in infected olive plants by duplex, nested polymerase chain reaction. Plant Disease, 87, 1487-1494.

Mercado-Blanco, J., Rodriguez-Jurado, D., Hervas, A., Jimenez-Diaz, R.M. (2004). Suppression of Verticillium wilt in olive planting stocks by root-associated fluorescent Pseudomonas spp. Biological Control, 30, 474-486.

Mercado-Blanco, J., Navarro-Raya, C., Valverde-Corredor, A., Amyotte, S.G., Dobinson, K.F., Prieto, P. (2009). A close look at the olive-Verticillium dahliae-Pseudomonas fluorescens in planta Interaction. Proceedings of the tenth International Verticillium Symposium. Corfu Island, Hellas p. 50.

Nagatzaam, M.P.M. (1995). Talaromyces flavus as a potential biocontrol agent for controlling Verticillium dahliae in potatoes. $6^{\text {th }}$ International Verticillium Symposium, Dead Sea, Israel Phytoparasitica, 23, 69.

Naraghi, L., Heydari, A. (2006). Study on the growth ability of Talaromyces flavus on different plant material residues for biological control of cotton wilt caused by Verticillium dahliae. $17^{\text {th }}$ Iranian Protection Congress, 2-5 Sep., p. 268.

Niu, S.-G., Jiang, S.-R., Tang, W.-H. (1999). Positive regulations of Pseudomonas fluorescens by carbendazim and its application in controlling cotton Verticillium wilt. Acta Phytophylacica Sinica 26, 171-176.

Perneel, M. (2006). The root rot pathogen Pythium myriotylum on cocoyam (Xanthosoma sagittifolium): intraspecific variability and biological control. PhD Thesis, Ghent University, Ghent, Belgium.

Prieto, P., Navarro-Raya, C., Valverde-Corredor, A., Amyotte, S.G., Dobinson, K.F., Mercado-Blanco, J. (2009). Colonization process of olive tissues by Verticillium dahliae and its in planta interaction with the biocontrol root endophyte Pseudomonas fluorescens PICF7. Microbial Biotechnology, 2, 499-511 
Raaijmakers, J.M., de Bruijn, I., de Kock, M.J.D. (2006). Cyclic lipopeptide production by plant-associated Pseudomonas species: diversity, activity, biosynthesis and regulation. Molecular Plant Microbe Interactaction, 19, 699-710.

Sanei, S.J., Nasrollahnejad, S. (1995). Aggresiveness of some Verticillium dahliae isolates to susceptible and resistant cultivars of cotton. Journal of Agricultural Sciences, 1, 6777 (Persian, with English summary).

Sanei, S.J., Razavi, S.E., Zarei, H., Latifi, N. 1996. Verticillium wilt of olive. Islamic Azad University, Gorgan branch, 16 p. (in Persian).

Sanei, S.J., Ebrahimi, A.Gh., Razavi, S.E. (2000). A relation between inoculum density of Verticillium dahliae and Verticillium wilt progression of cotton in Gorgan region. $14^{\text {th }}$ Iranian Protection Congress, 5-8 Sep., p. 53.

Sanei, S.J., Okhovvat, S.M., Hedjaroude, Gh.A., Saremi, H., Javan-Nikkhah, M. (2004). Olive verticillium wilt or dieback on olive in Iran. Applied and Biological Sciences, Ghent University 69, 433-442.

Sanei, S.J., Waliyar, F., Razavi, S.E., Okhovvat, S.M. (2008). Vegetative compatibility, host range and pathogenicity of Verticillium dahliae isolates in Iran. International Journal of Plant Production 2, 37-45.

Sanei, S.J., Okhovvat, S.M., Taheri, A.H. (2005). Investigation on diseases of Olive trees and seedlings in Iran $.57^{\text {th }}$ International Symposium on Crop Protection, Ghent University, p. 64.

Sanei, S.J., Razavi, S.E., Okhovvat, S.M., Pahlavani, M.H. (2010). Verticillium Wilts. Peik-eReihan publication, Gorgan, 652p, (in Persian).

Sanei, S.J., Razavi, S.E., Ghanbarnia, K. (2011). Fungi on Plants and Plant Products in Iran. Peik-e-Reihan publication, Gorgan, 680p (in Press).

Soesanto, L., Termorshuizen, A.J. (2001). Effect of temperature on the formation of microsclerotia of Verticillium dahliae. Journal of Phytopathology, 149, 685-691.

Mercado-Blanco, J., Rodriguez-Jurado, D., Hervas, A., Jimenez-Diaz, R.M. (2004). Suppression of Verticillium wilt in olive planting stocks by root-associated fluorescent Pseudomonas spp. Biological Control, 30, 474-486.

Prieto, P., Navarro-Raya, C., Valverde-Corredor, A., Amyotte, S.G., Dobinson, K.F., Mercado-Blanco, J. (2009). Colonization process of olive tissues by Verticillium dahliae and its in planta interaction with the biocontrol root endophyte Pseudomonas fluorescens PICF7. Microbial Biotechnology, 2, 499-511

Tjamos, E.C. (1993), Prospects and strategies in controlling verticillium wilt of olive. Bulletin OEPP/EPPO Bulletin, 23, 505-512.

Tjamos, E.C. (2000). Strategies in developing methods and applying techniques for the biological control of Verticillium dahliae-short review. in: Tjamos, E.C., Rowe, R.C., Heale, J.B., Fravel, D.R. (Eds.), Advances in Verticillium Research and Disease Management. St Paul, MN, USA: APS Press, pp. 227-231.

Tjamos, E.C., Biris, D.A., Paplomatas, E.J. (1991). Recovery of olive trees with Verticillium wilt after individual application of soil solarization in established olive orchards. Plant Disease 75, 557-562.

Tsror, L., Erlich, O., Amitai, S., Hazanovsky, M. (1998). Verticillium wilt of paprika caused by a highly virulent isolate of Verticillium dahliae. Plant Diseases 82, 437-439

Tsror, L., Hazanovsky, M., Mordechi-Lebiush, S., Sivan, S. (2001). Aggressiveness of Verticillium dahliae isolates from different vegetative compatibility groups to potato. Plant Pathology, 50, 477-482.

van Loon, L.C., Bakker, P.A.H.M., Pieterse, C.M. (1998). Systemic resistance induced by rhizosphere bacteria. Annual Review Phytopathology, 36, 453-483.

Velazhahan, R., Samiyappan, R., Vidhyasekaran, P. (1999). Relationship between antagonistic activities of Pseudomonas fluorescens isolates against Rhizoctonia solani 
and their production of lytic enzymes. Journal of Plant Diseases and Protection, 106, 244-250.

Wang, C.X., Wang, D.B., Zhou, Q. (2004). Colonization and persistence of a plant growthpromoting bacterium Pseudomonas fluorescens strain CS85, on roots of cotton seedlings. Canadian. Journal of Microbiology, 50, 475-481.

Wilhelm, S., Taylor, J.B. (1965). Control of Verticillium wilt of olive through natural recovery and resistance. Phytopathology, 55, 310-316.

Willetts, H.J., Bullock, S. (1992). Developmental biology and sclerotia. Mycological Research, 96, 801-816.

(C) 2011 Sanei and Razavi; This is an Open Access article distributed under the terms of the Creative Commons Attribution License (http://creativecommons.org/licenses/by/3.0), which permits unrestricted use, distribution, and reproduction in any medium, provided the original work is properly cited. 